\title{
Exogenous Nitric Oxide Inhibits Tumor Necrosis Factor-Alpha- or Interleukin-1-Beta-Induced Monocyte Chemoattractant Protein-1 Expression in Human Mesangial Cells
}

\author{
Role of IKB-Alpha and Cyclic GMP
}

\author{
Sang Koo Lee ${ }^{b}$ Choung Soo Kim ${ }^{a}$ Won Seok Yang ${ }^{b}$ Soon Bae Kim ${ }^{b}$ \\ Su-Kil Park ${ }^{b}$ J ung Sik Park ${ }^{b}$ \\ aDepartment of Internal Medicine, Urology, and bAsan Institute for Life Sciences, College of Medicine, \\ University of Ulsan, Seoul, Korea
}

\section{Key Words \\ IкB-alpha - Mesangial cells · Monocyte

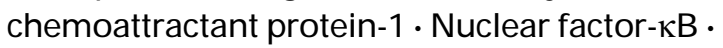 3-Morpholino-sydnonimine}

\begin{abstract}
Monocyte chemoattractant protein-1 (MCP-1) plays an important role in glomerulonephritis and nitric oxide (NO) exerts a variety of renal pathophysiological effects. We investigated the effect of exogenous NO on proinflammatory cytokine-induced MCP-1 expression in human mesangial cells and its signal transduction pathway. Cells were pretreated with NO donors such as 3morpholino-sydnonimine (SIN-1) or nitroprusside, and then stimulated with tumor necrosis factor- $\alpha$ (TNF- $\alpha$ ) or interleukin-1 $\beta$ (IL-1 $\beta$ ). MCP-1 expression of mRNA and protein were measured by Northern blot analysis and ELISA. NF-kB binding activity was determined by electrophoretic mobility shift assay. Degradation of IKB- $\alpha$ protein was assessed by Western blot analysis. SIN-1 inhibited TNF- $\alpha$ - or IL-1 $\beta$-induced MCP-1 mRNA expression in a dose-dependent manner and also suppressed
\end{abstract}

\section{KARGER}

Fax +41613061234 E-Mail karger@karger.ch www. karger.com
(C) 2002 S. Karger AG, Basel 0028-2766/02/0924-0780\$18.50/0

Accessible online at: www. karger.com/journals/nef the MCP-1 protein expression. Nitroprusside inhibited the MCP-1 mRNA expression as well. SIN-1 dose dependently inhibited the TNF- $\alpha$ - or IL-1 $\beta$-induced NF-KB binding activity and suppressed the TNF- $\alpha$-induced degradation of IKB- $\alpha$. Analogue of CGMP (8-bromo-cGMP) had no significant effect on TNF- $\alpha$-induced MCP-1 mRNA expression and guanylate cyclase inhibitor (ODQ) also had no significant influence on the inhibitory effect of SIN-1. These results suggest that exogenous NO inhibits MCP-1 expression via suppression of NF-KB by reducing the degradation of IKB- $\alpha$ and through a CGMP-independent pathway.

Copyright @2002S. Karger AG, Basel

\section{Introduction}

Monocyte infiltration is a common feature of many glomerular diseases. Monocytes infiltrating glomeruli secrete an array of cytokines and growth factors, which trigger a downstream cascade of glomerular injury [1]. Monocyte chemoattractant protein-1 (MCP-1) plays a key role in the recruitment of monocytes [2]. In addition to che- 
motactic activity, MCP-1 can induce calcium flux and respiratory burst activity, and also regulate the adhesion molecule expressions and cytokine productions in monocytes [3, 4]. It is also known that MCP-1 can stimulate the TGF- $\beta$ production in lung fibroblast [5].

Expression of MCP-1 is observed in the mesangium of inflamed glomeruli [6] and can be upregulated in response to pro-inflammatory cytokines such as tumor necrosis factor- $\alpha$ (TNF- $\alpha$ ) or interleukin-1 $\beta$ (IL-1 $\beta$ ) in mesangial cells [7]. Thus, MCP-1 produced by activated mesangial cells may play an important role during glomerular inflammation. Therefore, inhibiting the local expression of MCP-1 by pharmacological agents can be a possible therapeutic approach to glomerulonephritis.

Nitric oxide (NO), a biologically active compound synthesized from the guanidino group of $L$-arginine, is involved in the regulation of many physiologic functions including endothelium-dependent vasodilation, neurotransmission, and cell-mediated immune response. Alterations in NO synthesis are implicated in the pathophysiology of inflammation, septic shock and atherosclerosis $[8,9]$.

Although the role of NO in glomerular diseases is controversial, a number of studies have indicated that enhancing renal NO activity shows a beneficial change in renal pathology and function in animals with glomerulonephritis [10-13]. However, little has been known about the effects of exogenous NO on MCP-1 expression in human mesangial cells.

Studies of the human MCP-1 promoter suggest that nuclear factor- $\mathrm{KB}(\mathrm{NF}-\mathrm{\kappa B})$ is essential to the induction of $\mathrm{MCP}-1$ gene expression [14]. NF- $\mathrm{kB}$ is an important regulator of genes involved in immune and inflammmatory responses and is activated by phosphorylation and degradation of its bound inhibitor protein, IкB- $\alpha$ [15].

It has been widely assumed that the effect of NO is mediated by the activation of guanylate cyclase and cGMP formation [8], but controversies still exist [1618].

In this study, we investigated the effect of exogenous NO such as 3-morpholino-sydnonimine (SIN-1) and nitroprusside on the TNF- $\alpha$ - or IL-1 $\beta$-induced MCP-1 expression in human mesangial cells and the possible role of NF- $\kappa \mathrm{B}, \mathrm{I} \kappa \mathrm{B}-\alpha$ and $\mathrm{cGMP}$.

\section{Methods}

\section{Reagent}

RPMI medium and other cell culture reagents were obtained from Gibco BRL, Grand Island, N.Y., USA. Human MCP-1 ELISA kit (Quantikine) and human recombinant TNF- $\alpha$ and IL-1 $\beta$ were obtained from R\&D Systems Inc., Minneapolis, Minn., USA. Tri Reagent Kit ${ }^{\circledR}$ was obtained from Molecular Research Center, Inc., Cincinnati, Ohio, USA. 3-Morpholino-sydnonimine (SIN-1) and nitroprusside were obtained from Sigma Chemical Company, St Louis, Mo., USA. IкB $\alpha$ antibody kit was from Cell Signaling Technology, Beverly, Mass., USA. Double-stranded NF-кB oligonucleotides were obtained from Promega, Madison, Wisc., USA.

\section{Human Mesangial Cell Culture}

Human glomerular mesangial cells were isolated from a normal portion of nephrectomized tissues from patients with renal cancer. The renal cortex was minced and glomeruli were isolated by the differential sieving method. After exposure to $0.1 \%$ collagenase (Gibco, Gaithersburg, USA), the glomeruli were placed in a tissue culture flask and cultured in RPMI 1640 culture media supplemented with $11.5 \mathrm{~m} M$ Hepes, $26.2 \mathrm{~m} M$ sodium bicarbonate, penicillin (100 U/ $\mathrm{ml})$, streptomycin $(100 \mu \mathrm{g} / \mathrm{ml})$, fungizone $(250 \mathrm{ng} / \mathrm{ml})$ and $20 \%$ fetal calf serum at $37^{\circ} \mathrm{C}$ in $5 \% \mathrm{CO}_{2}$. The media were changed every 3 days and cells were subcultured by exposing to $0.05 \%$ trypsin and $0.02 \%$ EDTA, when they became confluent. Characterization of mesangial cells and culture purity were assessed by phase-contrast microscopy and by immunofluorescence staining, which revealed characteristic actin-positive cytoskeletal components that were negative for cytokeratin and factor VIII antigens.

\section{Cell Culture Conditioning}

To evaluate the effect of SIN-1 on the MCP-1 expression, mesangial cells were serum-starved for $24 \mathrm{~h}$. After serum starvation, cells were exposed to tumor necrosis factor- $\alpha(\mathrm{TNF}-\alpha, 10 \mathrm{ng} / \mathrm{ml})$ or interleukin- $1 \beta$ (IL-1 $\beta 1 \mathrm{ng} / \mathrm{ml})$ for the indicated periods in the presence or absence of SIN-1 (0.1-1 $\mathrm{m} M)$ [16]. Effect of another NO donor, nitroprusside (NP, $2 \mathrm{~m} M$ ) on the TNF- $\alpha$ - or IL- $1 \beta$-induced MCP-1 mRNA expression was also examined [16]. Cell viability measured by trypan blue exclusion was not adversely effected by these NO donors in this experiments.

MCP-1 mRNA and protein expression were measured using Northern blot analysis and ELISA, respectively. To assess the effect

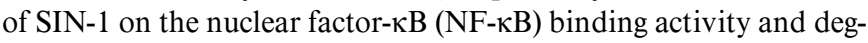
radation of cytoplamic I $\kappa \mathrm{B}-\alpha$, electrophoretic mobility shift assay and Western blot analysis were performed, respectively. To determine whether the effect of SIN-1 was mediated by guanylate cyclase and cGMP, inhibitor of NO-sensitive guanylate cyclase, $1 \mathrm{H}-[1,2,4]$ oxadiazolo[4,3-a]quinoxalin-1-one (ODQ) and analogue of cGMP, 8-bromo-cGMP was used.

\section{Northern Blot Analysis}

Total cellular RNA was extracted using a commercially available modification of the acid-phenol method (Tri reagent kit ${ }^{\circledR}$ ). Northern hybridization was performed as previously described [19]. Briefly, RNA $(10 \mu \mathrm{g} /$ lane) was electrophoresed through $1 \%$ agarose, $2.2 \mathrm{M}$ formaldehyde denaturing gel with MOPS buffer, followed by capillary transfer to nylon membranes. Filters were stained with methylene blue, to check the integrity, uniformity of loading and transfer of RNA, prior to fixation in vacuo at $80^{\circ} \mathrm{C}$ for $2 \mathrm{~h}$. Filters were pre- 
hybridized at $65^{\circ} \mathrm{C}$ in $0.5 M \mathrm{NaHPO}_{4}$ buffer, $\mathrm{pH} 7.0,1 \mathrm{~m} M$ EDTA, $7 \%$ sodium dodecyl sulfate and $1 \%$ bovine serum albumin for $4-6 \mathrm{~h}$. Then filters were hybridized with ${ }^{32} \mathrm{P}$-labeled cDNA probes and $100 \mu \mathrm{g} / \mathrm{ml}$ salmon sperm DNA at $65^{\circ} \mathrm{C}$ overnight. cDNA probes were labeled with ${ }^{32} \mathrm{P}$ using random primers (Megaprime ${ }^{\mathrm{TM}}$ DNA labeling system, Amersham International, England). Filters were washed and exposed to film at $-80^{\circ} \mathrm{C}$. cDNA probes specific for human MCP-1 and GAPDH (glyceraldehyde-3-phosphate-dehydrogenase) were made by reverse transcription-polymerase chain reaction (RT-PCR) method, as previously described [19]. The sequences of each PCR primer set were as follows:

MCP-1: forward primer 5' AAGCTCGCACTCTCGCCTC 3', backward primer 5' CAGGGTGTCTGGGGAAAGC 3'; GAPDH: forward primer 5' TCACCATCTTCCAGGAGCG 3', backward primer 5' CTGCTTCACCACCTTCTTGA 3'.

The same filters were rehybridized with a cDNA specific for GAPDH to correct for variation in RNA loading and transfer efficiency.

Enzyme-Linked Immunosorbent Assay (ELISA)

Mesangial cells at a density of $5 \times 10^{5}$ cell were seeded into $60 \mathrm{~mm}$ culture dish with $2 \mathrm{ml}$ media. After serum starvation for $24 \mathrm{~h}$, cells were exposed to TNF- $\alpha(10 \mathrm{ng} / \mathrm{ml})$ or IL- $1 \beta 1 \mathrm{ng} / \mathrm{ml})$ for $24 \mathrm{~h}$ in the presence or absence of SIN-1 (1 mM).

MCP-1 protein level in cell culture supernatant was measured by ELISA. The ELISA method was an specific sandwich enzyme immunoassay (Human MCP-1 kit, Quantikine, R\&D). Briefly, diluted cell culture supernant was added to 96 well microtiter plate that was coated with murine monoclonal antibody against human MCP-1. After incubation at room temperature for $2 \mathrm{~h}$ and careful washes, polyclonal antibody conjugated to horseradish peroxidase against MCP-1 was added. After another incubation for $1 \mathrm{~h}$ at room temperature and repeated washes, color reagents were added. Optical density of each well was measured at $450 \mathrm{~nm}$ with an ELISA reader, using $570 \mathrm{~nm}$ reference wavelength.

\section{Extraction of Nuclear Protein and Electrophoretic Mobility Shift}

Assay

Nuclear extracts were prepared by modification of a method described previously [19]. Briefly, cells were gently washed twice with ice-cold PBS and scraped in $1 \mathrm{ml}$ of ice-cold hypotonic lysis buffer (10 m $M$ HEPES-KOH, pH 7.9, $60 \mathrm{~m} M \mathrm{KCl}, 1 \mathrm{~m} M$ EDTA, $1 \mathrm{~m} M$ dithiothreitol, $1 \mathrm{~m} M$ PMSF and $0.5 \%$ Nonidet P-40). The cells were vortexed and allowed to swell on ice for $10 \mathrm{~min}$. The nuclei were collected by centrifugation at $2,000 \mathrm{rpm}$ for $5 \mathrm{~min}$ at $4{ }^{\circ} \mathrm{C}$.

The nuclear pellet were resuspended in $100 \mu \mathrm{l}$ of high salt extraction buffer (20 m $M$ HEPES-KOH, pH 7.9, $0.42 M \mathrm{NaCl}, 1.2 \mathrm{~m} M$ $\mathrm{MgCl}_{2}, 0.5 \mathrm{~m} M$ DTT, $0.2 \mathrm{~m} M$ EDTA, 25\% glycerol, $0.5 \mathrm{~m} M$ PMSF, $5 \mu \mathrm{g} / \mathrm{ml}$ aprotinin, $5 \mu \mathrm{g} / \mathrm{ml}$ leupeptin) and incubated for $20 \mathrm{~min}$ on ice with shaking. The nuclear extract was then centrifuged for $15 \mathrm{~min}$ at $4^{\circ} \mathrm{C}$, and the supernatant was aliquoted and stored at $-80^{\circ} \mathrm{C}$.

Electrophoretic mobility shift assay was performed by incubation of nuclear protein $(7.5 \mu \mathrm{g})$ with ${ }^{32} \mathrm{P}$-labeled NF- $\mathrm{KB}$ oligonucleotides at room temperature for $20 \mathrm{~min}$ in binding buffer containing $50 \mathrm{mM}$ Tris, pH 7.5, $250 \mathrm{mM} \mathrm{NaCl}, 20 \%$ glycerol, $5 \mathrm{mM} \mathrm{MgCl} 2,2.5 \mathrm{~m} M$ EDTA, $2.5 \mathrm{~m} M$ DTT, $0.25 \mathrm{mg} / \mathrm{ml}$ poly (dI-dC). NF- $\mathrm{KB}$ oligonucleotides (5'-AGTTGAGGGGACTTTCCCAGGC-3') were labeled with $\gamma-{ }^{32} \mathrm{P}-\mathrm{ATP}$ using T4 kinase and purified on a Sephadex G-25 column. Nucleoprotein-oligonucleotide complexes were resolved by electrophoresis on $4 \%$ non-denaturing polyacrylamide gels in $0.25 \times \mathrm{TBE}$ buffer. The gel was dried and autoradiographed with intensifying screen at $-70^{\circ} \mathrm{C}$.

\section{Western Blot Analysis for I $\mathrm{KB} \alpha$}

Cytoplasmic extracts were prepared from cells and resolved on $10 \%$ SDS-polyacrylamide gels, transferred to nylon membrane and block overnight in TBS $(10 \mathrm{~m} M$ Trs, $\mathrm{pH} 7.5,150 \mathrm{~m} M \mathrm{NaCl})$ containing $0.5 \%$ Tween 20 and $5 \%$ nonfat milk. Membranes were then incubated for $2 \mathrm{~h}$ with primary antibody for IкB $\alpha$. Antibody-antigen complexes were detected with the aid of horseradish peroxidase-conjugated secondary antibody and chemiluminescence (ІкB $\alpha$ Antibody Kit, Cell Signaling Technology).

\section{Statistical Analysis}

The data were expressed as mean \pm SE. Groups were compared using an analysis of variance test for multiple group comparison (Scheffé's method). $\mathrm{p}<0.05$ was considered to indicate a statistically significant difference.

\section{Results}

\section{Exogenous NO such as SIN-1 and NP Inhibited the} TNF- $\alpha$ - or IL-1 $\beta$-Induced MCP-1 Expression

Mesangial cells were preincubated with varying dose of SIN-1 $(0.1-1 \mathrm{mM})$ for $30 \mathrm{~min}$ and then stimulated with TNF- $\alpha(10 \mathrm{ng} / \mathrm{ml})$ or IL- $1 \beta(1 \mathrm{ng} / \mathrm{ml})$ for $6 \mathrm{~h}$. Total RNA was prepared and MCP-1 mRNA expression was analyzed by Northern blot analysis. Northern blot analysis revealed that TNF- $\alpha$ - or IL- $1 \beta$ - induced increase in MCP1 mRNA expression was markedly inhibited by SIN-1 in a dose-dependent manner $(0.1-1 \mathrm{~m} M)$. Treatment with SIN-1 alone had no effect on basal MCP-1 mRNA expression (fig. 1).

MCP-1 protein level in cell culture supernatant was determined from mesangial cells stimulated by TNF- $\alpha$ or IL- $1 \beta$ with or without SIN- 1 for 24 h. TNF- $\alpha$ and IL-1 $\beta$ increased the MCP-1 protein levels to around $14.7 \pm 0.7$ and $9.6 \pm 0.4$ fold, respectively, when compared to control cells. SIN-1 $(1 \mathrm{~m} M)$ significantly inhibited the TNF- $\alpha$ - or IL- $1 \beta$-induced MCP- 1 protein levels by 75.8 \pm 2.0 and $70.8 \pm 0.6 \%$, respectively, when compared to TNF- $\alpha$ - or IL-1 $\beta$-induced MCP-1 protein level (fig. 2).

Another NO donor, nitroprusside $(2 \mathrm{mM})$, also suppressed the TNF- $\alpha$ - or IL- $1 \beta$-induced increase in MCP-1 mRNA expression (fig. 3).

\section{Dose-Dependent Suppression of TNF- $\alpha$ - or \\ $I L-1 \beta$-Induced NF- $\kappa B$ Binding Activity by SIN-1}

It has been reported that activation of NF- $\mathrm{KB}$ is essential for the induction of MCP-1 gene [14]. To determine whether SIN-1 inhibited the TNF- $\alpha$ - or IL-1 $\beta$-induced activation of NF-KB in human mesangial cells, electro- 
Fig. 1. Dose-dependent inhibition of TNF$\alpha$ - or IL-1 $\beta$-induced MCP-1 mRNA expression by SIN-1. Mesangial cells were preincubated with varying dose of SIN-1 (0.1$1 \mathrm{mM}$ ) for $30 \mathrm{~min}$ and then stimulated with TNF- $\alpha(10 \mathrm{ng} / \mathrm{ml})$ or IL- $1 \beta(1 \mathrm{ng} / \mathrm{ml})$ for $6 \mathrm{~h}$. MCP-1 mRNA expression was analyzed by Northern hybridization. Northern blot was representative of three separate experiments.

Fig. 2. Inhibition of TNF- $\alpha$ - or IL-1 $\beta$-induced MCP-1 protein expression by SIN-1 . Mesangial cells were preincubated with SIN-1 $(1 \mathrm{mM})$ for $30 \mathrm{~min}$ and then stimulated with $10 \mathrm{ng} / \mathrm{ml} \mathrm{TNF}-\alpha$ (a) or $1 \mathrm{ng} / \mathrm{ml} \mathrm{IL-1} \beta$ (b) for $24 \mathrm{~h}$. MCP-1 protein levels in cell culture supernatant were measured by ELISA. Data were mean \pm SE of 6 samples. ${ }^{\#} \mathrm{p}<$ 0.05 vs. control, ${ }^{\#} \mathrm{p}<0.05$ vs. TNF- $\alpha$ or IL$1 \beta$.

Fig. 3. Inhibition of TNF- $\alpha$ - or IL-1 $\beta$-induced MCP-1 mRNA expression by nitroprusside. Mesangial cells were preincubated with nitroprusside (NP, $2 \mathrm{mM}$ ) for $30 \mathrm{~min}$ and then stimulated with TNF- $\alpha(10 \mathrm{ng} / \mathrm{ml})$ or IL-1 $\beta(1 \mathrm{ng} / \mathrm{ml})$ for $6 \mathrm{~h}$. MCP-1 mRNA expression was analyzed by Northern hybridization. Northern blot was representative of three separate experiments.

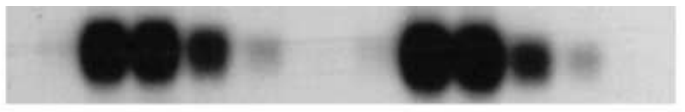

$\operatorname{MCP}-1(0.74 \mathrm{~Kb})$

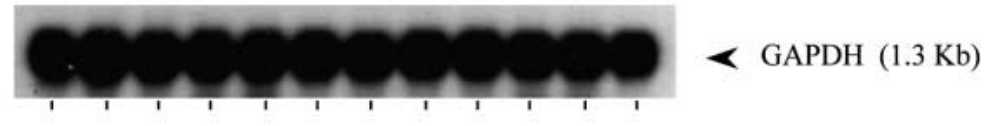

TNF- $\alpha$

IL-1 $\beta$

SIN-1 $\quad-\quad-\quad \begin{array}{llllllllllll} & 0.1 & 0.5 & 1 & 1 & - & - & 0.1 & 0.5 & 1 & 1 & \mathrm{mM}\end{array}$
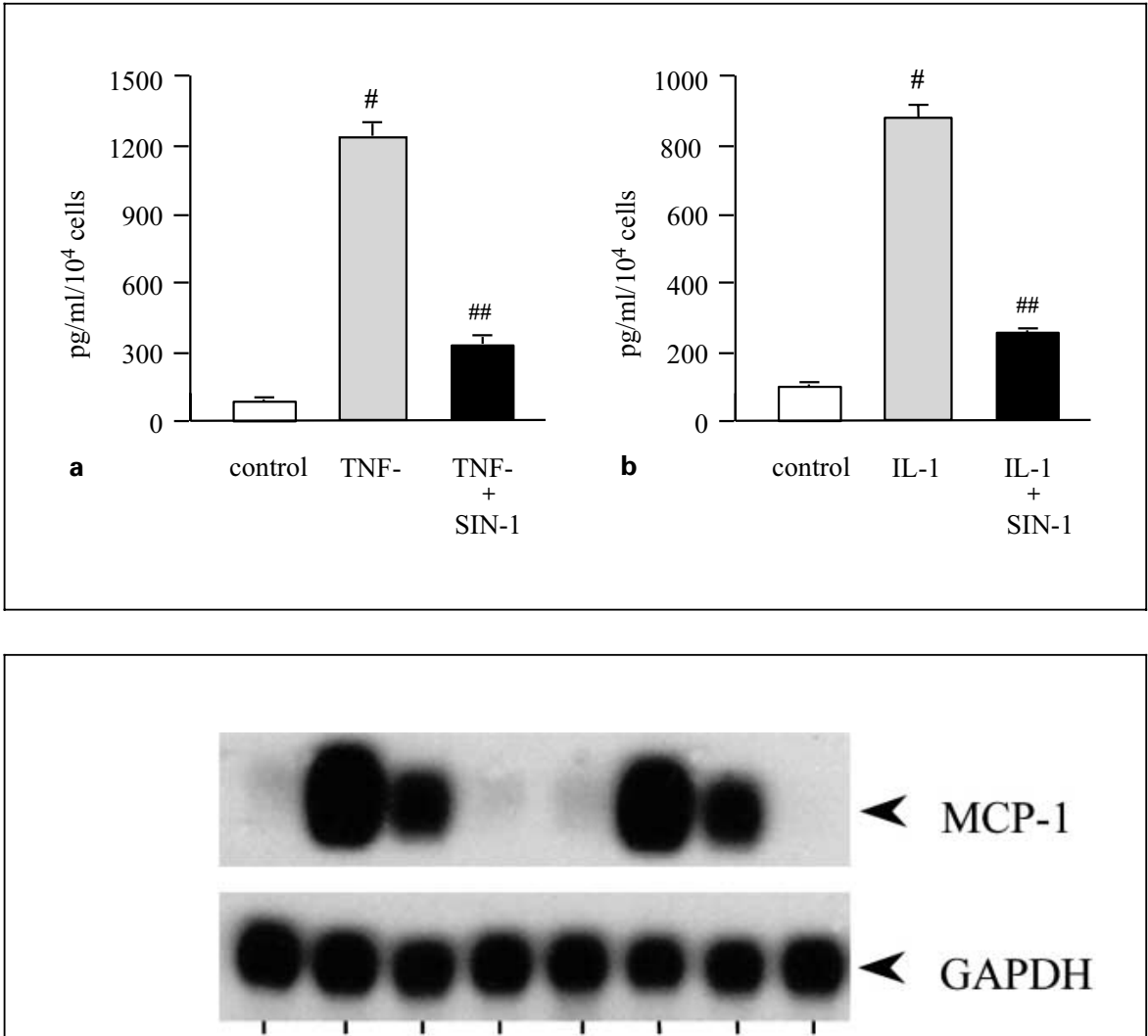

TNF- $\alpha-++$

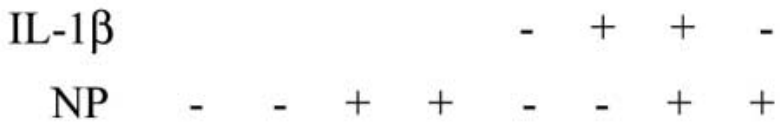


Fig. 4. Dose-dependent suppression of TNF- $\alpha$ - or IL- $1 \beta$-induced NF- $\kappa B$ binding activity by SIN-1. Mesangial cells were preincubated with varying dose of SIN-1 (0.1$1 \mathrm{mM}$ ) for $30 \mathrm{~min}$ and then stimulated with $10 \mathrm{ng} / \mathrm{ml} \mathrm{TNF}-\alpha$ (a) or $1 \mathrm{ng} / \mathrm{ml} \mathrm{IL-1} \beta$ (b) for $1 \mathrm{~h}$. Nuclear protein extracts were subjected to electrophoretic mobility shift assays. Similar results were obtained in three separate experiments. n.s. $=$ Nonspecific binding.

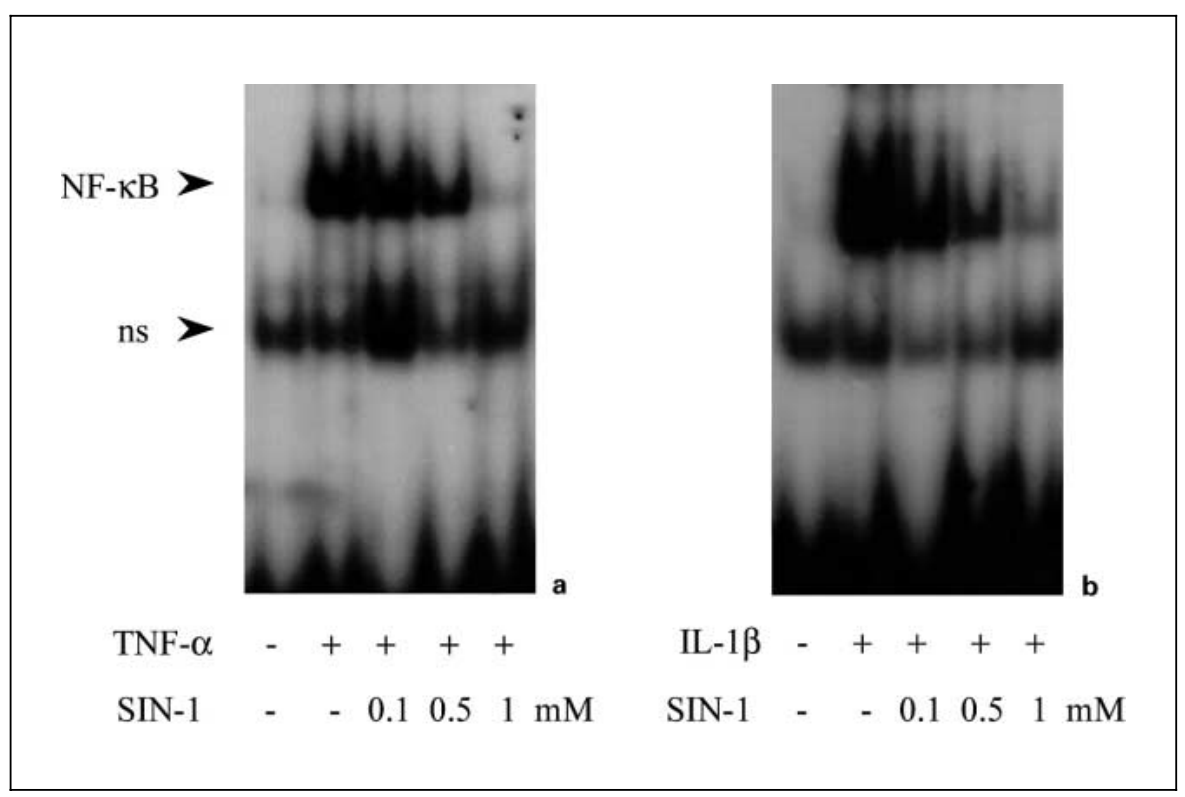

phoretic mobility shift assays (EMSA) was performed. EMSA revealed that both TNF- $\alpha$ and IL- $1 \beta$ increased the NF- $\kappa B$ binding activity and SIN-1 suppressed the TNF- $\alpha-$ or IL-1 $\beta$-induced NF- $\kappa B$ binding activity in a dose-dependent manner (0.1-1 $\mathrm{m} M)$ (fig. 4). These results suggested that the inhibitory effect of SIN- 1 on the TNF- $\alpha$ - or IL$1 \beta$-induced MCP-1 expression was mediated, at least in part, by inhibition of NF- $\kappa \mathrm{B}$ activation.

\section{Inhibition of TNF- $\alpha$-Induced Degradation of I $\kappa B-\alpha$ by SIN-1}

The translocation of NF- $\mathrm{KB}$ to the nucleus is preceded by the phosphorylation and proteolytic degradation of IкB- $\alpha$ [15]. IkB- $\alpha$ level was measured at 0,5 and $10 \mathrm{~min}$ after stimulation with TNF- $\alpha(10 \mathrm{ng} / \mathrm{ml})$. Western blot analysis revealed that TNF- $\alpha$ induced the degradation of IkB- $\alpha$ almost completely at 10 min of stimulation (fig. 5a). Therefore, to evaluate the effect of SIN-1 on the TNF$\alpha$-induced IkB- $\alpha$ degradation, IkB $\alpha$ level was measured at 10 min after stimulation with TNF- $\alpha$ in the presence or absence of SIN-1 (1 mM). Western blot analysis revealed that SIN-1 $(1 \mathrm{~m} M)$ markedly suppressed the TNF- $\alpha-$ induced degradation of I $\mathrm{KB}-\alpha$ (fig. $5 b$ ), suggesting that SIN-1-induced inhibition of NF- $\kappa B$ binding activity was mediated, at least in part, by inhibition of I $\kappa \mathrm{B}-\alpha$ degradation.

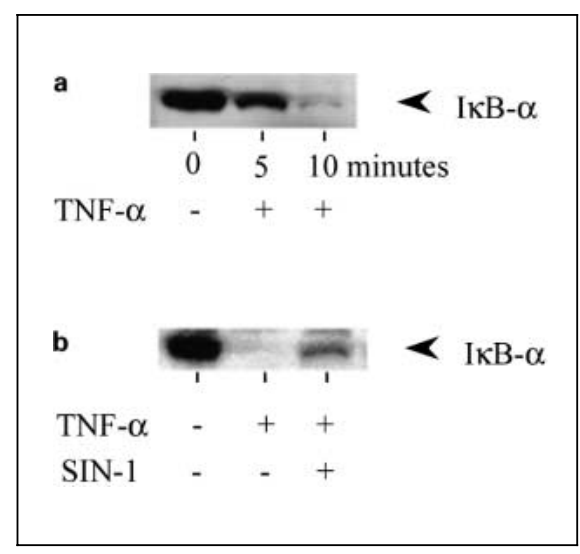

Fig. 5. Inhibition of TNF- $\alpha$-induced degradation of cytoplasmic IкB$\alpha$ by SIN-1. Mesangial cells were stimulated with TNF- $\alpha(10 \mathrm{ng} / \mathrm{ml})$ for the indicated time (a). Mesangial cells were preincubated with SIN-1 $(1 \mathrm{~m} M)$ for $30 \mathrm{~min}$ and then stimulated with TNF- $\alpha$ for 10 min (b). Cytoplasmic protein extracts were subjected to Western blot analysis. Similar results were obtained in three separate experiments.

\section{Inhibitory Effect of SIN-1 on the TNF- $\alpha$-Induced $M C P-1$ mRNA Expression Was Independent of Guanylate Cyclase and cGMP Formation}

It has been widely assumed that the effect of NO is mediated by activation of guanylate cyclase and cGMP formation. To determine the involvement of guanylate cyclase or cGMP in the inhibitory effect of SIN-1, we 


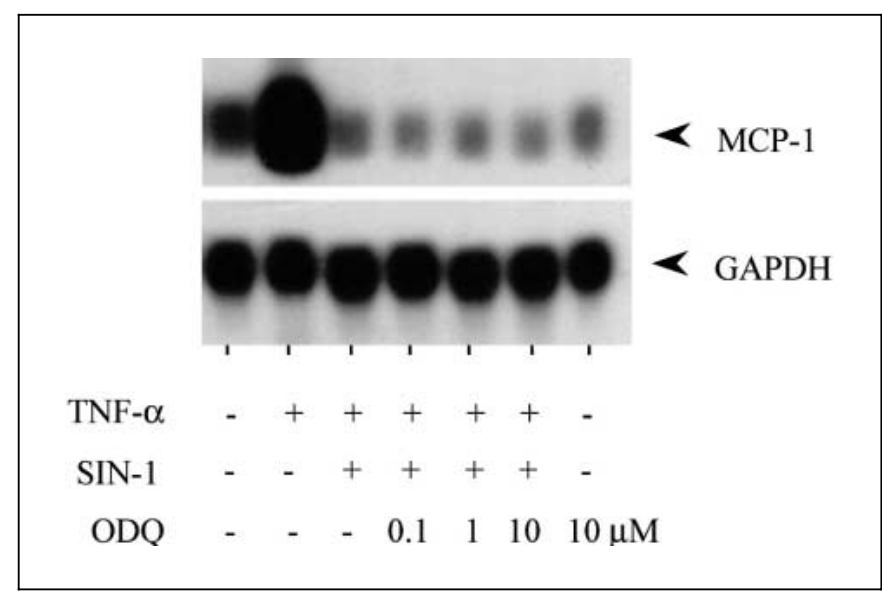

Fig. 6. Effect of a guanylate cyclase inhibitor (ODQ) on the SIN1 -induced inhibition of MCP-1 mRNA expression. Mesangial cells were preincubated with varying dose of ODQ $(0.1-10 \mu M)$ for $30 \mathrm{~min}$ in the presence or absence of SIN-1 $(1 \mathrm{mM})$ and then stimulated by TNF- $\alpha(10 \mathrm{ng} / \mathrm{ml})$ for $6 \mathrm{~h}$. MCP- $1 \mathrm{mRNA}$ expression was analyzed by Northern hybridization. Northern blot was representative of three separate experiments.

examine the effect of a NO-sensitive guanylate cyclase inhibitor, ODQ and a potent, stable membrane-permeable analogue of cGMP, 8-bromo-cGMP. Northern blot analysis revealed that addition of ODQ $(0.1-10 \mu M)$ had no significant influence on the inhibitory effect of SIN-1 (fig. 6). Furthermore, addition of 8-bromo-cGMP (0.01$1 \mathrm{~m} M$ ) showed no significant effect on the TNF- $\alpha$ induced MCP-1 mRNA expression (fig. 7). These results suggested that inhibitory effect of SIN-1 on the MCP-1 mRNA expression was independent of guanylate cyclase and cGMP formation.

\section{Discussion}

MCP-1 has been reported to play a key role in the recruitment of monocytes into glomeruli. In addition to its role in cellular immune reactions and responses to acute tissue injury, MCP-1 has been suggested as an important mediator in human diseases such as atherosclerosis, glomerulonephritis and melanoma [6, 20,21].

Activation of transcription factor NF- $\mathrm{KB}$ leads to control of genes for the expression of cytokines, chemokines, immunoreceptors, cell adhesion molecules, growth factors, and acute phase proteins, which play an important roles in immune and inflammmatory responses [15]. Therefore, pharmacologic inhibitors of MCP-1 and NF-

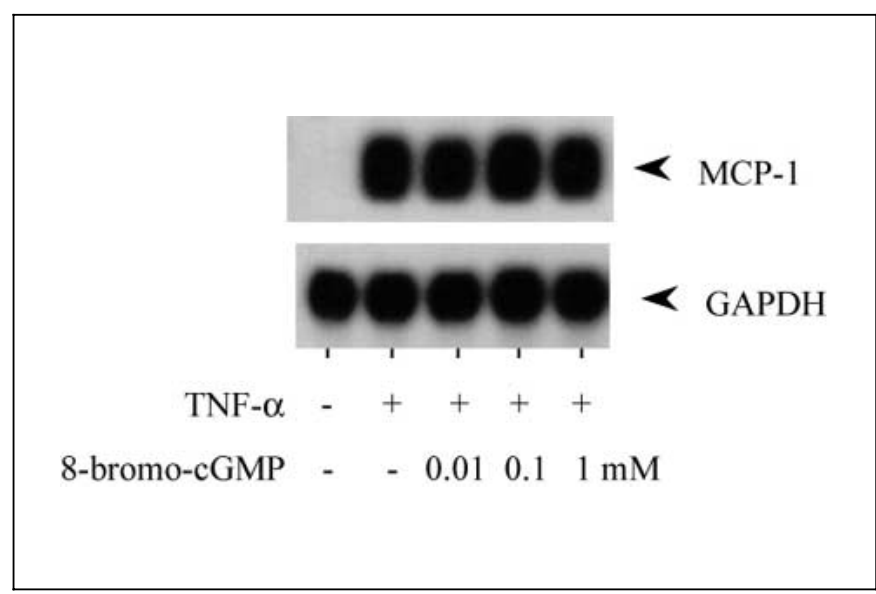

Fig. 7. Effect of 8-bromo-cGMP on the TNF- $\alpha$-induced MCP-1 mRNA expression. Mesangial cells were preincubated with varying dose of 8-bromo-cGMP (0.01-1 $\mathrm{m} M)$ for $30 \mathrm{~min}$ and then stimulated by TNF- $\alpha(10 \mathrm{ng} / \mathrm{ml})$ for $6 \mathrm{~h}$. MCP- 1 mRNA expression was analyzed by Northern hybridization. Northern blot was representative of three separate experiments.

$\kappa \mathrm{B}$ may serve as useful agents for the treatment of glomerulonephritis.

Nitric oxide (NO) has been identified as an effector molecule with multiple biologic functions such as cell cytotoxicity, modulation of immune response and antiinflammatory effect. Since the effect of NO potentially can be toxic or preventive, there is as yet no clear understanding of how it affects the pathogenesis of glomerulonephritis. In experimental glomerulonephritis, high levels of NO production is induced in glomeruli, suggesting its involvement in the pathogenesis of glomerulonephritis, but its role has not been defined well by the effect of NO inhibition. Furthermore, reports about the effect of NO inhibition showed somewhat conflicting results $[22,23]$. On the other hand, it has been suggested that an intact constitutive NO release within the glomerular vasculature may be protective by decreasing the glomerular capillary pressure [22, 23].

A number of recent studies have suggested that enhancing renal NO activity shows a beneficial change in renal pathology and function in animals with glomerulonephritis [10-13]. Furthermore, exogenous nitric oxide has protective effect on the renal function and inflammatory response in a rat model of ischemia-reperfusion [24], prevents endotoxin-induced glomerular thrombosis in rats [25] and reduces endothelial dysfunction caused by hypertension in rats [26]. However, little has been known 
about the effects of exogenous NO on the MCP-1 expression in human mesangial cells.

In this study, we evaluated the effect of exogenous NO such as SIN-1 and nitroprusside on the pro-inflammatory cytokine-induced MCP-1 expression in human mesangial cells. Next, we investigated the signal transduction pathway underlying the effect of SIN-1.

We found that SIN-1 inhibited the TNF- $\alpha-$ or IL- $1 \beta-$ induced MCP-1 mRNA expression in a dose-dependent manner and also suppressed the MCP-1 protein expression. Furthermore, another NO donor, nitroprusside, inhibited the TNF- $\alpha$ - or IL-1 $\beta$-induced MCP-1 mRNA expression as well. Therefore, exogenous NO may be useful for preventing the MCP-1- mediated glomerular injury.

Other exogenous NO donors such as C87-3736 and DETA-NO (donor ethamine 2,2'[hydroxynitrisohydrazonon]bis) has been also reported to inhibit MCP-1 expression in other cell types such as endothelial cells and smooth muscle cells [27, 28].

Besides inhibitory effect on the MCP-1 expression in mesangial cells, exogenous $\mathrm{NO}$ has been reported to inhibit mesangial cell adhesion to extracellular matrix components [29], suppress mesangial intercellular adhesion molecule-1 expression [16] and inhibit mesangial transforming growth factor- $\beta$ and collagen synthesis [30].

It is well known that NF- $\mathrm{KB}$ is essential to the induction of MCP-1 gene expression and NF- $\mathrm{-B}$ is activated by degradation of its bound inhibitor protein, IкB- $\alpha[14$, $15]$.

We found that SIN-1 dose dependently inhibited the TNF- $\alpha$ - or IL-1 $\beta$-induced NF- $\mathrm{KB}$ binding activity and suppressed the TNF- $\alpha$-induced degradation of IкB- $\alpha$ in mesangial cells. These results suggest that inhibitory effect of SIN-1 on the MCP-1 expression in human mesangial cells is mediated, at least in part, via suppression of NF$\kappa \mathrm{B}$ by reducing the degradation of I $\mathrm{KB}-\alpha$. Other exogenous NO donors such as nitroprusside, S-nitroso-N-acetylpenicillamine and S-nitrosoglutathione has been also reported to inhibit the degradation of IкB- $\alpha$ in mesangial and endothelial cells [18, 31].

It is widely assumed that the effect of $\mathrm{NO}$ is mediated by activation of guanylate cyclase and cGMP formation [8]. However, it has been suggested that regulatory pathway of exogenous NO may be different from that of endogenous NO [16-18]. Mitsutomi et al. [32] demonstrated that endogenous NO inhibited endothelin-1 production through guanynyl cyclase/cGMP-dependent pathway in porcine aortic endothelial cells, whereas exogenous NO inhibited endothelin-1 production through a guanyl cyclase/cGMP-independent pathway.

We found that a guanylate cyclase inhibitor, ODQ, had no significant influence on the inhibitory effect of SIN-1 and also the analogue of cGMP, 8-bromo-cGMP, had no significant effect on the TNF- $\alpha$-induced MCP-1 mRNA expression. These results suggest that inhibitory effect of SIN-1 on the MCP-1 expression is not mediated through the guanyl cyclase/cGMP-dependent pathway.

In summary, exogenous NO may be useful for glomerulonephritis by downregulating the mesangial MCP-1 expression via suppression of NF- $\mathrm{KB}$ by reducing the degradation of IкB- $\alpha$ and through a cGMP-independent pathway.

\section{Acknowledgments}

This work was supported by a research grant from the Asan Institute for Life Science, Seoul, Korea. The authors thank Joo Yeol Park for his excellent technical assistance in cell culture and Northern blot analysis.

\section{References}

1 Atkins RC: Macrophages in renal injury. Am J Kidney Dis 1998;31:45-47.

2 Leonard EJ, Yoshimura T: Human monocyte chemoattractant protein-1 (MCP-1). Immunol Today 1990;11:97-101.

3 Rollins BJ, Walz A, Baggiolini M: Recombinant human MCP-1/JE induces chemotaxis, calcium flux and the respiratory burst in human monocytes. Blood 1991;78:1112-1116.

4 Jiang Y, Beller DI, Frendl G, Graves DT: Monocyte chemoattractant protein-1 regulates adhesion molecule expression and cytokine production in human monocytes. J Immunol 1992;148:2423-2428.
5 Gharaee-Kermani M, Denholm EM, Phan SH: Costimulation of fibroblast collagen and transforming growth factor beta 1 gene expression by monocyte chemoattractant protein-1 via specific receptors. J Biol Chem 1996;271: 17779-17784.

6 Rovin BH, Rumancik M, Tan L, Dickerson J: Glomerular expression of monocyte chemoattractant protein-1 in experimental and human glomerulonephritis. Lab Invest 1994;71:536542.

7 Stahl RAK: Chemoattractive (chemokine) and immune renal injury. Nephrol Dial Transplant 1995; 10:307-319.
8 Moncada S, Higgs A: The $L$-arginine-nitric oxide pathway. N Eng J Med 1993;329:20022012.

9 Vane JR, Mitchell JA, Appleton I, Tomlinson A, Bishop-Bailey D, Croxtall J, Willoughby DA: Inducible isoforms of cyclooxygenase and nitric-oxide synthase in inflammation. Proc Natl Acad Sci USA 1994;91:2046-2050.

10 Ashab I, Peer G, Blum M, Wollman Y, Chernihovsky T, Hassner A, Schwartz D, Cabili S, Silverberg D, Iaina A: Oral administration of $L$ arginine and captopril in rats prevents chronic renal failure by nitric oxide production. Kidney Int 1995;47:1515-1521. 
11 Maree A, Peer G, Iaina A, Blum M, Wollman Y, Chernihovsky T, Silverberg DS, Cabili S: Nitric oxide in streptozotocin-induced diabetes melitus in rats. Clin Sci 1996;90:379-384.

12 Reyes AA, Purkerson ML, Karl I, Klahs S: Dietary supplementation with $L$-arginine ameliorates the progression of renal disease in rats with subtotal nephrectomy. Am J Kidney Dis 1992;20:168-176.

13 Hertzan-Levy S, Fish R, Skutelsky E, Wollman $\mathrm{Y}$, Chernihovsky T, Polak-Charcon $\mathrm{S}$ Schwartz D, Blum M, Cabili S, Iaina A: Glomerular basement membrane anion sites in adriamycin nephropathy: Effect of saline loading and nitric oxide modulation. Nephron 2000;84:354-361.

14 Shyy YJ, Li YS, Kolattukudy PE: Activation of MCP-1 gene expression is mediated through multiple signaling pathways. Biochem Biophys Res Comm 1993;192:693-699.

15 Wardle EN: Nuclear factor $\kappa \mathrm{B}$ for the nephrologist. Nephrol Dial Transplant 2001;16:17641768.

16 Ikeda M, Ikeda U, Takahashi M, Shimada K, Minota S, Kano S: Nitric oxide inhibits intracellular adhesion molecule-1 expression in rat mesangial cells. J Am Soc Nephrol 1996;7: 2213-2218.

17 De Caterina R, Libby P, Peng HB, Thannickal VJ, Rajavashisth TB, Gimbrone MA Jr, Shin WS, Liao JK: Nitric oxide decreases cytokineinduced endothelial activation: Nitric oxide selectively reduces endothelial expression of adhesion molecules and proinflammatory cytokines. J Clin Invest 1995;96:60-68.
18 Peng HB, Libby P, Liao JK: Induction and stabilization of $\mathrm{I} \kappa \mathrm{B}-\alpha$ by nitric oxide mediates inhibition of NF-кB. J Biol Chem 1995;270: 14214-14219.

19 Lee SK, Kim BS, Yang WS, Kim SB, Park SK, Park JS: High glucose induces MCP-1 expression partly via tyrosine kinase-AP-1 pathway in peritoneal mesothelial cells. Kidney Int 2001; 60:55-64.

20 Nelken NA, Coughlin SR, Gordon D, Wilcox $\mathrm{JN}$ : Monocyte chemoattractant protein-1 in human atheromatous plaque. J Clin Invest 1991;88:1121-1127.

21 Graves DT, Barnhill R, Galanopoulos T, Antoniades $\mathrm{HN}$ : Expression of monocyte chemotactic protein-1 (MCP-1) in human melanoma in vivo. Am J Pathol 1992;140:9-14.

22 Cattel V: Nitrix oxide and glomerulonephritis. Semin Nephrol 1999; 19:277-287.

23 Ketteler M, Distler A: The role of nitric oxide in experimental glomerulonephritis. Kidney Blood Press Res 1996;19:177-181.

24 Garcia-Criado FJ, Eleno N, Santos-Benito F, Valduniciel JJ, Reverte M, Lozano-Sanchez FS, Ludena MD, Gomez-Alonso, Lopez-Novoa JM: Protective effect of exogenous nitric oxide on the renal function and inflammatory response in a model of ischemia-reperfusion. Transplantation 1998;66:982-990

25 Westberg G, Schulz PJ, Raij L: Exogenous nitric oxide prevents endotoxin-induced glomerular thrombosis in rats. Kidney Int 1994;46: 711-716.
26 Otsuka Y, Harasawa S, Sugiura H, Koike M, Akimoto H, Ishii T, Abeta H, Okabe T, Kushiro $\mathrm{T}$, Kanmatsuse K: The effect of exogenous nitric oxide on endothelial dysfunction in twokidney, one-clip renovascular hypertensive rats. Jpn J Nephrol 2000;42:619-624.

27 Zeiher AM, Fisslthaler B, Schray-Utz B, Busse $\mathrm{R}$ : Nitric oxide modulates the expression of monocyte chemoattractant protein 1 in cultured human endothelial cells. Circ Res 1995: 76:980-986.

28 Tsao PS, Wang BY, Buitrago R, Shyy JYJ, Cooke JP: Nitric oxide regulates monocyte chemotactic protein-1. Circulation 1997;96:934940.

29 Yao J, Schoecklmann HO, Prols F, Gauer S, Sterzel RB: Exogenous nitric oxide inhibits mesangial cell adhesion to extracellular matrix components. Kidney Int 1998;53:598-608.

30 Craven PA, Studer RK, Felder J, Phillips S, Derubertis FR: Nitric oxide inhibition of transforming growth factor- $\beta$ and collagen synthesis in mesangial cells. Diabetes 1997;46:671-681.

31 Diaz-Cazorla, Perez-Sala, Lamas S: Dual effect of nitric oxide donors on cyclooxgenase-2 expression in human mesangial cells. J Am Soc Nephrol 1999;10:943-952.

32 Mitsutomi N, Akashi C, Odagiri J, Matsumura $\mathrm{Y}$ : Effects of endogenous and exogenous nitric oxide on endothelin-1 production in cultured vascular endothelial cells. Eur J Pharmacol 1999;364:65-73. 